\title{
Effects of habitat degradation on avian guilds in East African papyrus Cyperus papyrus swamps
}

\author{
ILYA M. D. MACLEAN, MARK HASSALL, ROSALIND BOAR and OLIVER \\ NASIRWA
}

\section{Summary}

The density and species richness of bird communities in disturbed and undisturbed stands of papyrus Cyperus papyrus were compared. Point counts, corrected for different probabilities of detection in different swamps, suggested that the species richness of bird communities in stands of papyrus disturbed by burning, grazing or pollution was higher than in nearby stands that were not disturbed. However, there were fewer species and individuals of highly specialized birds or species characteristic of papyrus, in disturbed stands than in undisturbed swamps. At $<1 \mathrm{ha}^{-1}$, the density of Papyrus Gonolek Laniarius mufumbiri in Ugandan swamps was, for example, significantly lower in polluted and burnt sites than in undisturbed papyrus where up to $13 \mathrm{ha}^{-1}$ were recorded in the centre of swamps. White-winged Swamp Warbler Bradypterus carpalis was only recorded in undisturbed papyrus. In the papyrus that fringes Lake Naivasha in Kenya, outside the geographical range of species restricted to papyrus, disturbance in the form of grazing selects against species classified as swamp-reliant. Species classified as generalist users of papyrus were much less sensitive to disturbance than specialists. The density of swamp specialists was also lower near the edge of swamps, where total species richness was higher. These results are discussed in relation to conservation management of papyrus swamps in East Africa.

\section{Introduction}

Papyrus Cyperus papyrus bird communities are thought to be amongst the least well protected birds in East Africa (Muriuki et al. 1997, Bennun and Njoroge 1999) and, in many places, their habitat is under immediate threat of degradation or loss (Britton 1978, Vande weghe 1981, Muriuki et al. 1997, Boar et al. 1999). Several East African species are entirely, or almost entirely, restricted to papyrus (Britton 1978, Vande weghe 1981). One of these, Papyrus Yellow Warbler Chloropeta gracilirostris is threatened globally and is classed as Vulnerable. Papyrus Gonolek Laniarius mufumbiri is considered Near Threatened (BirdLife International 2000). Several other species utilize papyrus, particularly around the edges of swamps. Although these birds may benefit from the presence of papyrus, they are not entirely reliant on this habitat.

In addition to clearance for agriculture and papyrus harvesting, swamps are particularly prone to three forms of habitat degradation: herbivore grazing and trampling, burning, and pollution (Vande weghe 1981, Mafabi 2000). Due to the 
current status of papyrus avian communities and continued stress on their habitat as a result of human activities, there is an urgent need to determine the impact of these forms of degradation on papyrus avian communities. These forms of degradation are unlikely to affect all species uniformly. In this study we therefore used avian guilds to draw comparisons between degraded and undegraded stands of papyrus.

Few studies of the birds of papyrus swamps have been conducted. Britton (1978) used mark-release-recapture to examine the seasonality, density and diversity of birds in a papyrus swamp near Lake Kanyaboli in western Kenya and Nasirwa (unpubl. data) examined the effects of vegetation structure on mistnet capture rates. Vande weghe (1981) proposed that altitude and rainfall were major influences on papyrus-associated birds in Rwanda and Burundi. In none of these studies were any quantitative comparisons between sites included. In this study we use point counts for estimating density and species richness in papyrus and develop a technique for comparing the species richness of sites with different probabilities of detecting birds.

\section{Method}

Study areas and sampling sites

Three types of degraded swamp were selected for study and compared with undegraded stands of papyrus in Uganda and Kenya (Figure 1). Sites were chosen where papyrus was influenced heavily by grazing at Lake Naivasha, Kenya $(1,890 \mathrm{~m})$, by burning on the north shores of Lake Victoria, Uganda $(1,135$ $\mathrm{m})$ and by organic and industrial pollution at Kinawataka, south-east of Kampala, Uganda $(1,185 \mathrm{~m})$. Each of these three swamps showed symptoms of only one type of habitat degradation. In the Lake Naivasha and Kinawataka swamps, stands of apparently undegraded swamp within $5 \mathrm{~km}$ of the disturbed sites were also selected. For Kinawataka swamp, a valley-bottom swamp in south-western Uganda $\left(0^{\circ} 24^{\prime} \mathrm{N}, 30^{\circ} 24^{\prime} \mathrm{E}, 1,190 \mathrm{~m}\right)$ with similar rainfall to Kampala (c. 1,400 $\mathrm{mm}$ ) was selected for comparison. At the time of sampling, none of the swamps selected as controls showed any symptoms of current or recent degradation. All the undisturbed swamps were of similar size, shape and isolation to the swamps to which they were compared. Moreover, the surrounding topography and edge habitat were also similar between pairs of disturbed and undisturbed sites. Lake Naivasha differed from other sampling areas in that it was outside the geographical range of birds restricted to papyrus. Swamps subjected to pollution, burning or grazing can all be viewed as disturbed, if disturbance is taken to mean "any relatively discrete event in time that disrupts ecosystem, community or population structure and changes resources, substrate availability or the physical environment" (White and Pickett 1985).

\section{Species richness estimates}

In each swamp between 10 and 23 randomly located point counts were made, to calculate the mean species richness per point count in each swamp. All counts were conducted by the same observer between July and August 2001. The rar- 


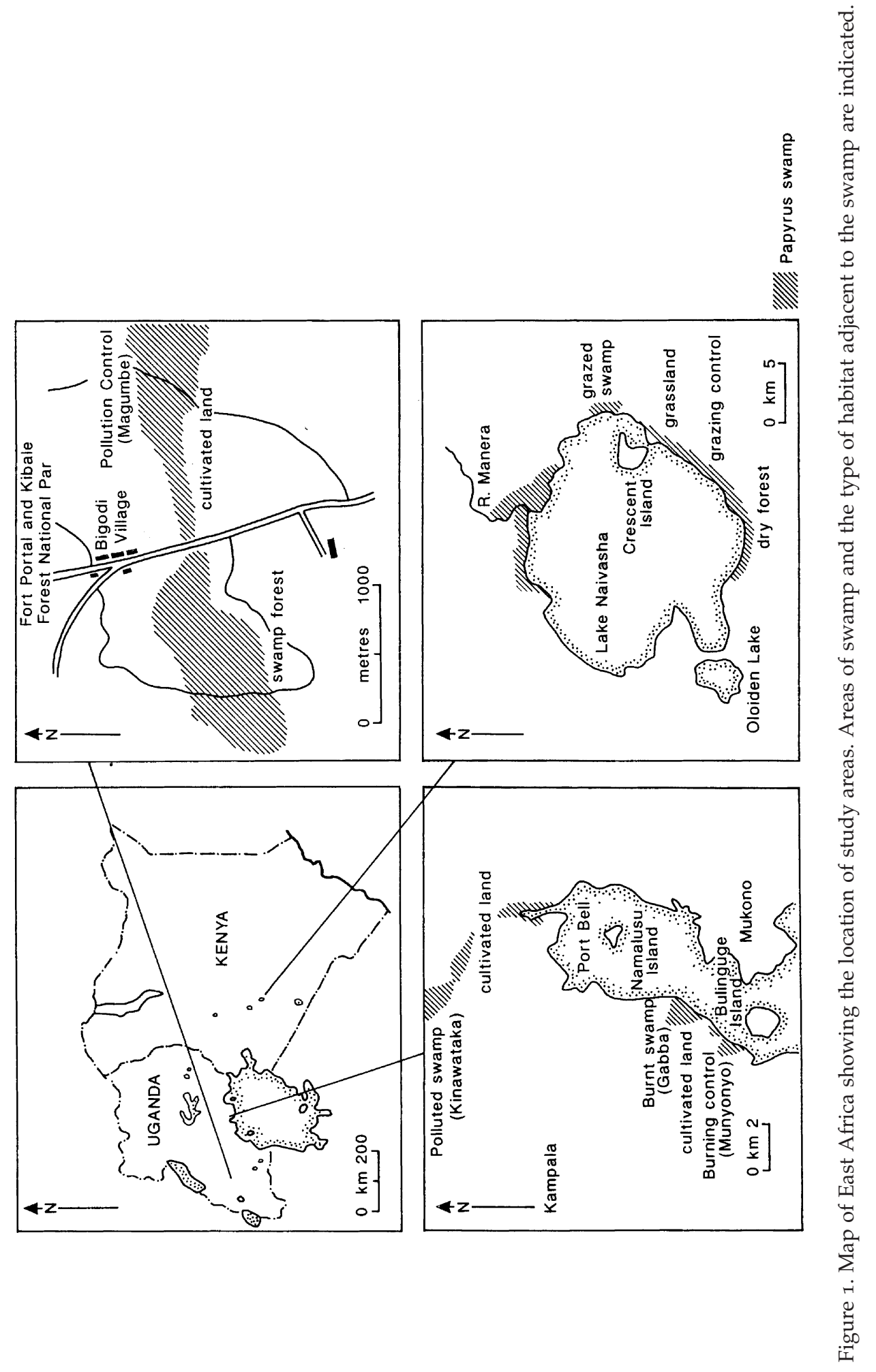


efaction method (Hurlbert 1971) was also used to estimate the expected species richness of a sample of 30 individuals in each swamp. Between o6hoo and 1ohoo, birds were located either aurally or visually, identified, and their distance to the observer estimated. Distance of the sampling point to the landward edge of the swamp was measured directly or estimated from GPS readings. A sketch map was drawn to indicate the proportion of each sampling site that was covered by papyrus. The structure of the plant community that dominated the landward edge of each sampling site was recorded. Plant communities were classified as cultivated, grassland, dry forest or swamp forest.

In the smaller swamps, much of the area within which birds were detectable lay outside the swamp. Consequently, the area sampled by each point count differed. Moreover, probability of detection varied between disturbed and undisturbed stands because of very large differences in density of papyrus stems. For this reason, DISTANCE 3.5 software (Thomas et al. 1998) was used to calculate probability of detection functions for all species combined. First, data were grouped into $10 \mathrm{~m}$ distance intervals and evaluated for goodness of fit with detection probability function models. We evaluated uniform, half-normal and hazard-rate functions, selecting functions using lowest Aikake's Information Criterion (Buckland et al. 1993). An area/detectability product was then determined (area of swamp sampled multiplied by the probability of detection of a bird) and was held constant in analyses of data collected from each point where counts were made. This was achieved by calculating cut-off distances beyond which all birds located were ignored. Details of how cut-off distances were calculated are given in Appendix 1.

\section{Density estimates}

The density of birds in each swamp was estimated by dividing the number of birds recorded in each swamp by the area of swamp sampled and their probability of detection using DISTANCE. As some of the point counts were conducted near the edge of the swamp, and thus part of the area sampled within the cut-off distance lay outside the swamp, the area of swamp was estimated to the nearest $5 \mathrm{~m}^{2}$ from sketch maps. Data were grouped into $10 \mathrm{~m}$ intervals and uniform, half-normal and hazard-rate models with cosine adjustments of order, evaluated for goodness of fit again using lowest Aikake's Information Criterion. Comparisons were made between the density of birds in the interior $(>25 \mathrm{~m})$ of swamps with those near the edges $(<25 \mathrm{~m})$. Densities were calculated using the same probability of detection function for both categories, and estimating the total area of papyrus sampled by point counts, using the sketch maps.

\section{Species guilds}

Each species encountered during the study was assigned to one of the following guilds depending upon the strength of its association with papyrus swamp. Notes on habitat use are taken from Mackworth-Praed and Grant (1960) and Fry et al. (2000). 
Table 1. Estimated species richness of 30 individual birds in pairs of disturbed and undisturbed papyrus swamp in East Africa. Estimates were made using the rarefaction method (Hurlbert 1971).

\begin{tabular}{lll}
\hline Form of disturbance & Species richness in disturbed & Species richness in control \\
\hline Pollution & 11.83 & 11.41 \\
Burning & 12.59 & 8.65 \\
Grazing & 10.06 & 5.32 \\
\hline
\end{tabular}

Papyrus-restricted species. Papyrus Gonolek, Papyrus Canary Serinus koliensis and White-winged Swamp Warbler are entirely restricted to papyrus (Vande weghe 1981). Carruthers's Cisticola Cisticola carruthersi, Greater Swamp Warbler Acrocephalus rufescens and Papyrus Yellow Warbler are restricted locally to papyrus (Britton 1978, Vande weghe 1981, Fry et al. 2000).

Swamp-reliant species. These are reliant on tall emergent swamp vegetation, but, in many cases, not papyrus. Where papyrus-restricted species are present, several species of warblers may, for example, be restricted to other swamp vegetation or to the edges of papyrus swamp, e.g. Lesser Swamp Warbler Acrocephalus gracilirostris.

Swamp-opportunist species. These birds are usually found in swampy areas, but are not reliant on tall emergent swamp vegetation and may be found far from a swamp, e.g. Winding Cisticola Cisticola galactotes.

Open water associated species. These birds are often found in swamps and forage in or around open water. Most are piscivorous, such as kingfishers, and will use emergent vegetation fringing open water for roosting or as hunting perches. The category includes birds such as jacanas, which are reliant on water lilies and floating vegetation fringing lakeside swamps.

Generalist species. These are not typical of lakeside or swamp habitats, and are found in a wide variety of habitats. All birds not assigned to one of the other categories were assigned here. Some swamp forest or other edge habitat specialists were included.

\section{Results}

In total, 56 species were recorded in the study (Appendix 2). Six of these were classed as papyrus-restricted, three as reliant upon swamp habitat, 11 species as swamp-opportunists with four species associated with open water. Of the species found $32(57 \%)$ were habitat generalists.

The species richness of 30 individuals, estimated using the rarefaction method, ranged from 5.3 to 12.6 species (Table 1). Mean species richness per point count in the grazed swamp was significantly greater than in the nearby undisturbed swamp $\left(t_{21}=3.48, P=0.002\right)$, although other differences in species richness between swamps were insignificant (Figure 2).

The overall trend appears to be that disturbance results in a decrease in special- 


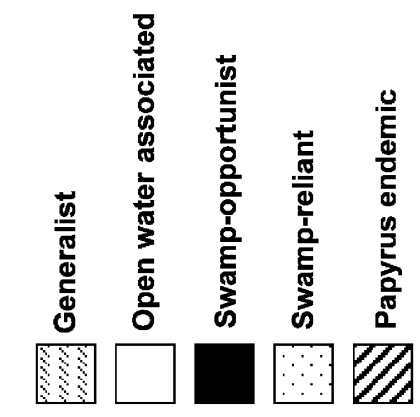


Table 2. Student $(t)$ values, degrees of freedom $(d f)$ and levels of significance $(P)$, indicating the differences in the number of bird species belonging to each guild, between disturbed and control swamps as shown in Figure 2.

\begin{tabular}{llllllllrrr}
\hline & \multicolumn{3}{c}{ Polluted vs. control } & \multicolumn{3}{c}{ Burnt vs. control } & \multicolumn{3}{c}{ Grazed vs. control } \\
& $t$ & $d f$ & $P$ & $t$ & $d f$ & $P$ & $t$ & $d f$. & $P$ \\
\hline Generalist & 1.98 & 22 & 0.061 & 2.75 & 27 & 0.011 & 5.32 & 21 & $<0.001$ \\
Open water associated & - & - & - & 2.29 & 27 & 0.030 & 0.79 & 21 & 0.436 \\
Swamp-opportunist & 3.79 & 22 & 0.001 & 1.08 & 27 & 0.289 & 5.39 & 21 & $<0.001$ \\
Swamp-reliant & 3.51 & 22 & 0.002 & 1.67 & 27 & 0.106 & 3.99 & 21 & 0.001 \\
Papyrus-restricted & 1.84 & 22 & 0.079 & 5.36 & 27 & $<0.000$ & - & - & - \\
\hline
\end{tabular}

ist species, but an increase in generalist species. For example, the number of papyrus-restricted species recorded in undisturbed swamps was more than in disturbed swamps, where in total, only two of the papyrus-restricted species (Papyrus Gonolek and Carruthers's Cisticola) were recorded. The species richness of generalists was greater in both the swamps disturbed by grazing and burning, although pollution made no difference to the number of generalist species (Figure 2, Table 2).

The mean number of open water associated species was lower in burnt than unburnt swamp, although this can be explained by the distance from open water at which burnt swamps were sampled as the burnt swamp was sampled more than $100 \mathrm{~m}$ from the waters edge. No differences in open water associated species between other pairs of disturbed and undisturbed swamp were found (Figure 2, Table 2). More swamp-opportunist species were supported by grazed and polluted papyrus than the corresponding undisturbed swamps, but there was no difference in the richness of swamp-opportunists between the burnt and unburnt papyrus (Figure 2, Table 2). There were fewer swamp-reliant species in grazed swamp but more in polluted papyrus than in the corresponding undisturbed swamps. Burning had a significant impact on the mean richness of papyrusrestricted species, whereas pollution appeared to make little difference (Figure 2, Table 2). There is no open water at Magumbe swamp and Kinawataka swamp and consequently no open water associated species were recorded at these swamps.

In two of the three control swamps, distance from the edge of the swamp appeared to make a difference to total species richness, with the edges of undisturbed swamps supporting similar avian communities to disturbed swamps (Figure 3). Mean species richness of birds in the centre ( $>25 \mathrm{~m}$ from the edge) of control swamps was compared with that near the landward edges $(<25 \mathrm{~m}$ from the edge). Both the pollution control swamp, Magumbe, in western Uganda and also the burning control swamp, Munyonyo, on the shores of Lake Victoria had a greater species richness near the edge (Figure 3; at Magumbe: $t_{16}=2.42$, $P=0.028$; at Munyonyo: $t_{21}=2.36, P=0.028$ ). However, this is primarily due to the number of generalist species, as the richness of generalists was higher near the edges at both these sites (Figure 3, Table 3). Conversely, the richness of papyrus-restricted species was higher in the centre of swamps at both these sites (Figure 3, Table 3).

At Lake Naivasha, in Kenya, where the undisturbed swamp was surrounded by grassland, the overall species richness in the centre of the swamp did not 


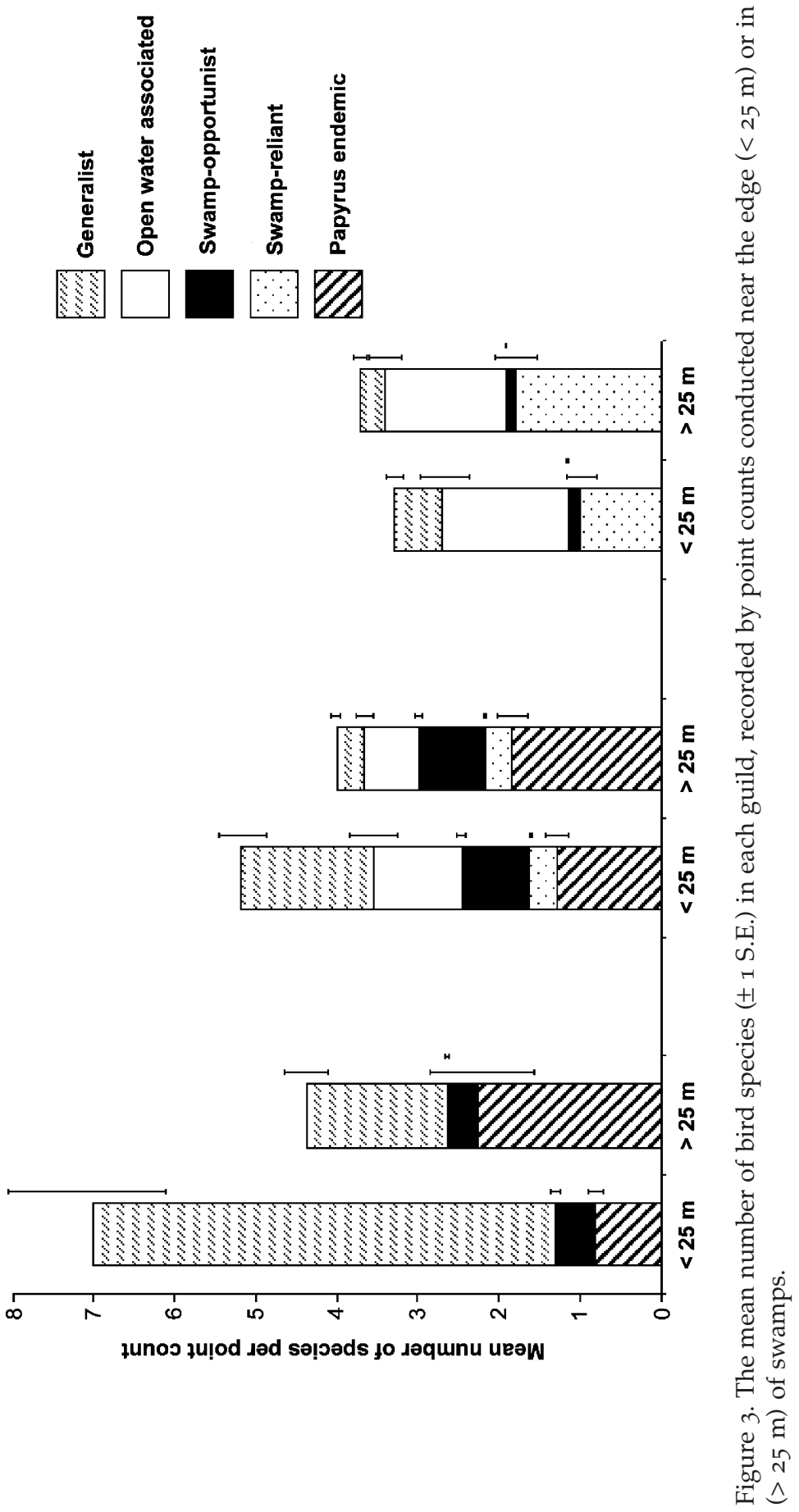


Table 3. Student $t$ values, degrees of freedom $(d f)$ and levels of significance $(P)$, indicating the differences in the number of bird species belonging to each guild, between the edge and centre of control swamps as shown in Figure 3.

\begin{tabular}{lllllllllll}
\hline & \multicolumn{3}{l}{ Pollution control } & \multicolumn{3}{c}{ Burning control } & \multicolumn{3}{c}{$\begin{array}{l}\text { Grazing control } \\
\text { centre vs. edge }\end{array}$} & \multicolumn{3}{c}{ centre vs. edge } & \multicolumn{3}{c}{ centre vs. edge } \\
& $t$ & $d f$ & $P$ & $\mathrm{t}$ & $d f$ & $P$ & $\mathrm{t}$ & $d f$ & $P$ \\
\hline Generalist & 3.92 & 16 & 0.001 & 3.68 & 21 & 0.001 & 1.86 & 15 & 0.083 \\
Open water associated & - & - & - & 1.36 & 21 & 0.187 & 0.19 & 15 & 0.849 \\
Swamp-opportunist & 1.71 & 16 & 0.106 & 0.13 & 21 & 0.898 & 1.68 & 15 & 0.113 \\
Swamp-reliant & - & - & - & 1.20 & 21 & 0.245 & 2.58 & 15 & 0.021 \\
Papyrus-restricted & 2.42 & 16 & 0.028 & 2.36 & 21 & 0.028 & - & - & - \\
\hline
\end{tabular}

differ significantly from that near the edge (Figure 3). Nevertheless, the richness of swamp-reliant species was lower near the edge (Figure 3, Table 3). However, undisturbed papyrus at Lake Naivasha, bordered by dry woodland had a higher species richness than swamp bordered by grassland and a higher number of generalist and swamp-opportunist species (Table 4).

Because of the potential significance of papyrus-restricted species in the overall bird communities of the study sites, densities of the papyrus-restricted Whitewinged Swamp Warbler and Papyrus Gonolek were calculated. These species were chosen for density calculations as both were sufficiently abundant for reliable estimates to be made. Neither of these species were recorded at Lake Naivasha. Papyrus Gonolek occurred at lower densities in both the polluted swamp and burnt swamp, than in corresponding controls (Table 5). White-winged

Table 4. Point count bird species richness (mean \pm S.E), indicating the differences in the number of species belonging to each guild, in papyrus surrounded by dry forest and papyrus surrounded by grassland at Lake Naivasha in Kenya.

\begin{tabular}{llllll}
\hline Guild & Dry forest $( \pm$ S.E.) & Grassland $( \pm$ S.E. $)$ & $d f$ & $t$ & $P$ \\
\hline Generalist & $3.17 \pm 0.87$ & $0.29 \pm 0.14$ & 21 & 3.27 & 0.004 \\
Open water associated & $1.67 \pm 0.33$ & $1.53 \pm 0.23$ & 21 & 0.35 & 0.730 \\
Swamp-opportunist & $0.83 \pm 0.17$ & $0.12 \pm 0.08$ & 21 & 3.78 & 0.001 \\
Swamp-reliant & $1.00 \pm 0.37$ & $1.47 \pm 0.15$ & 21 & 1.17 & 0.255 \\
Total & $6.67 \pm 0.56$ & $3.41 \pm 0.32$ & 21 & 2.14 & 0.044 \\
\hline
\end{tabular}

Table 5. Density estimates (mean $\mathrm{ha}^{-1} \pm$ S.E.) of White-winged Swamp Warbler, Papyrus Gonolek Lesser Swamp Warbler and Little Rush Warbler in disturbed and control swamps.

\begin{tabular}{llcccr}
\hline & Disturbed site $( \pm$ S.E.) & Control site $( \pm$ S.E. $)$ & $d f$ & $t$ & \multicolumn{1}{c}{$P$} \\
\hline Pollution & & & & & \\
White-winged Swamp Warbler & $0.00 \pm 0.00$ & $10.29 \pm 2.77$ & 16 & 3.71 & 0.002 \\
Papyrus Gonolek & $0.16 \pm 0.17$ & $6.11 \pm 1.34$ & 16 & 4.40 & $<0.001$ \\
Burning & & & & & \\
White-winged Swamp Warbler & $0.00 \pm 0.00$ & $7.10 \pm 2.20$ & 27 & 3.23 & 0.003 \\
Papyrus Gonolek & $0.32 \pm 0.55$ & $9.06 \pm 3.34$ & 27 & 2.58 & 0.016 \\
Grazing & & & & & \\
Lesser Swamp Warbler & $1.02 \pm 0.47$ & $29.52 \pm 7.23$ & 21 & 3.93 & 0.001 \\
Little Rush Warbler & $0.00 \pm 0.00$ & $6.43 \pm 1.25$ & 21 & 5.14 & $<0.001$ \\
\hline
\end{tabular}


Table 6. Density estimates (mean \pm S.E. $\mathrm{ha}^{-1}$ ) of White-winged Swamp Warbler, Papyrus Gonolek, Lesser Swamp Warbler and Little Rush Warbler in the edge and centre of control swamps.

\begin{tabular}{lccccc}
\hline & Edge $( \pm$ S.E.) & Centre $( \pm$ S.E) & $d f$ & $t$ & $P$ \\
\hline Pollution control (Magumbe) & & & & & \\
White-winged Swamp Warbler & $4.78 \pm 1.85$ & $12.93 \pm 2.03$ & 16 & 2.97 & 0.009 \\
Papyrus Gonolek & $3.67 \pm 1.12$ & $9.17 \pm 1.55$ & 16 & 2.88 & 0.011 \\
Burning control (Munyonyo) & & & & & \\
White-winged Swamp Warbler & $3.41 \pm 1.76$ & $10.48 \pm 2.56$ & 21 & 2.28 & 0.033 \\
Papyrus Gonolek & $4.70 \pm 0.99$ & $13.06 \pm 3.34$ & 21 & 2.27 & 0.034 \\
Grazing control (Lake Naivasha) & & & & & \\
Lesser Swamp Warbler & $23.07 \pm 5.85$ & $35.28 \pm 6.25$ & 15 & 1.86 & 0.167 \\
Little Rush Warbler & $4.46 \pm 1.08$ & $8.09 \pm 1.55$ & 15 & 3.28 & 0.005 \\
\hline
\end{tabular}

Swamp Warbler was not found in disturbed sites, but occurred at densities significantly greater than zero in corresponding control sites. The densities of the swamp-reliant Lesser Swamp Warbler and Little Rush Warbler Bradypterus baboecala at Lake Naivasha were also calculated. A substantially lower density of Lesser Swamp Warblers occurred in papyrus disturbed by grazing than in the corresponding control, and no Little Rush Warblers occurred in this disturbed swamp (Table 5).

In addition to an overall reduction in the number of specialist species, the density of those specialist species most commonly recorded was also lower near the edges than in the centre of control swamps (Table 6). The densities of Papyrus Gonolek and White-winged Swamp Warbler were significantly lower near the edges of control swamps in which they were found, as was the density of Little Rush Warbler near the edge of the swamp at Lake Naivasha. However, Lesser Swamp Warblers showed no such significant difference at Lake Naivasha (Table 6).

\section{Discussion}

At between 7 to $10 \mathrm{ha}^{-1}$ and 6 to $10 \mathrm{ha}^{-1}$ respectively, the average densities of White-winged Swamp Warbler and Papyrus Gonolek recorded in undisturbed papyrus were lower than the estimates made by Britton (1978) using markrelease-recapture in western Kenya $\left(21 \mathrm{ha}^{-1}\right.$ and $\left.9 \mathrm{ha}^{-1}\right)$. To our knowledge, estimates of density of Lesser Swamp Warblers and Little Rush Warblers have not been made previously. At approximately 30 Lesser Swamp Warblers $\mathrm{ha}^{-1}$ and 7 Little Rush-Warblers $\mathrm{ha}^{-1}$, the results were again slightly lower than Britton's density estimates of other swamp species. Britton found 33 Greater Swamp Warblers $\mathrm{ha}^{-1}$. Although our density estimates are lower than those made by Britton, we agree that the overall density of birds in papyrus is very high. In Magumbe swamp, densities of over 60 birds ha ${ }^{-1}$ were recorded. Under ideal conditions, papyrus can sustain extremely high growth rates (Muthuri et al. 1989) and such high densities may be a result of the high productivity of papyrus. The lower density of individual species, however, may be due to edge effects. Because of potential interspecific competition between the papyrus-restricted species and generalists from surrounding habitats, predation or edge disturbances, density 
estimates of species restricted to papyrus were likely to be smaller near the edge of swamps. Furthermore, smaller swamps have a higher edge to area ratio, of relevance here because the swamps used in this study were less than 200 ha in size, considerably smaller than that studied by Britton, which formed part of an extensive swamp network $160 \mathrm{~km}^{2}$ in size. Density estimates from the interior of swamps would appear to confirm this theory. At approximately $13 \mathrm{ha}^{-1}$, the density of White-winged Swamp Warblers in the interior of Magumbe swamp, in western Uganda, for example, was closer to Britton's estimate.

Although the densities of swamp-reliant and papyrus-restricted species are lower near the edge of swamps, edge habitat appeared to have a greater influence on the richness of generalists and swamp associates than on the richness of swamp-reliant or papyrus-restricted species. Total species richness was highest close to the edge. This was observed also by Vande weghe (1981) who recorded higher richness of non-swamp species at swamp margins in the Akagera basin in Rwanda. At Magumbe and Munyonyo in Uganda, the species richness of generalists was higher near the edge of swamps. At Lake Naivasha this was not the case, possibly because the short-grazed grassland adjacent to this swamp contained few species of bird. The higher number of species, particularly generalists, found in the swamp surrounded by dry forest would appear to confirm this. It appears that the interface between papyrus and edge habitats, although often physically distinct, is less distinct in terms of its avian community. The avian community near the edge of undisturbed papyrus swamps was similar to that in disturbed swamps.

The intermediate disturbance hypothesis predicts that disturbance, particularly at intermediate intensity or frequency, increases species richness (Connell 1978). The results of this study lend support to these predictions in that species richness in this study was highest in papyrus swamps that had been disturbed. However, species least dependent upon papyrus were less likely to be recorded in disturbed swamps. Habitat generalists and swamp-opportunists favoured disturbance much more than swamp-reliant or papyrus-restricted species. Generalists were better represented in grazed and burnt swamps and opportunists in grazed and polluted swamps than in stands that were apparently undisturbed. Clearly, disturbance, particularly by burning and grazing, reduced the abundance of papyrus-reliant species. The density of Papyrus Gonolek was lower in polluted and burnt sites and White-winged Swamp Warblers were absent from both. At Lake Naivasha, outside the geographical range of papyrus-restricted species, disturbance appears to select against swamp-reliant species.

These findings parallel the case of forest bird communities, where disturbance by human activities does not favour specialist species, which as a group are of high conservation concern ( $\mathrm{O}^{\prime}$ Connell et al. 1998, Barlow et al. 2002) and several studies on Lepidoptera suggest these findings are not unique to birds (Brown and Hutchings 1997, Hamer et al. 1997). Specialist species may persist at high density, but if they are restricted to one habitat, the risk of their extinction through habitat loss or degradation is much greater than for species that occur also in less threatened habitats (Muriuki et al. 1997). We conclude therefore that species richness should not be used as a parameter to target conservation resources if no consideration is given to the extent to which species are specialists. 


\section{Acknowledgements}

We thank the British Ecological Society, the University of East Anglia and The Earthwatch Institute, Boston, U.S.A., for funding and logistically supporting work. We are grateful to the Office of the President of the Government of Kenya, the Uganda National Council of Science and Technology and NatureUganda for support and permission to carry out the research. Dr Lincoln Fishpool (BirdLife International), Professor Derek Pomeroy (Makarere University) and Dr Leon Bennun (National Museums of Kenya) helped greatly with the design and implementation of the work.

Appendix 1. Calculating cut-off distances.

An arbitrary cut-off distance of $50 \mathrm{~m}$ was chosen for a point count conducted near the edge of the swamp with the lowest probability of detecting birds. The probability of detecting birds beyond this distance is very low. The area sampled $\left(a_{\mathrm{s}}\right)$ was estimated from ground maps using the following formula:

$$
a_{s}=\frac{\pi}{12} \sum_{n=1}^{12} y_{n}^{2}
$$

where: $\quad y_{1}$ to $y_{12}$ are distances beyond which all birds located were ignored, taken at $30^{\circ}$ intervals as shown in Figure 4. Their length is either the cut-off distance or the distance to the edge of the swamp, which ever is less.

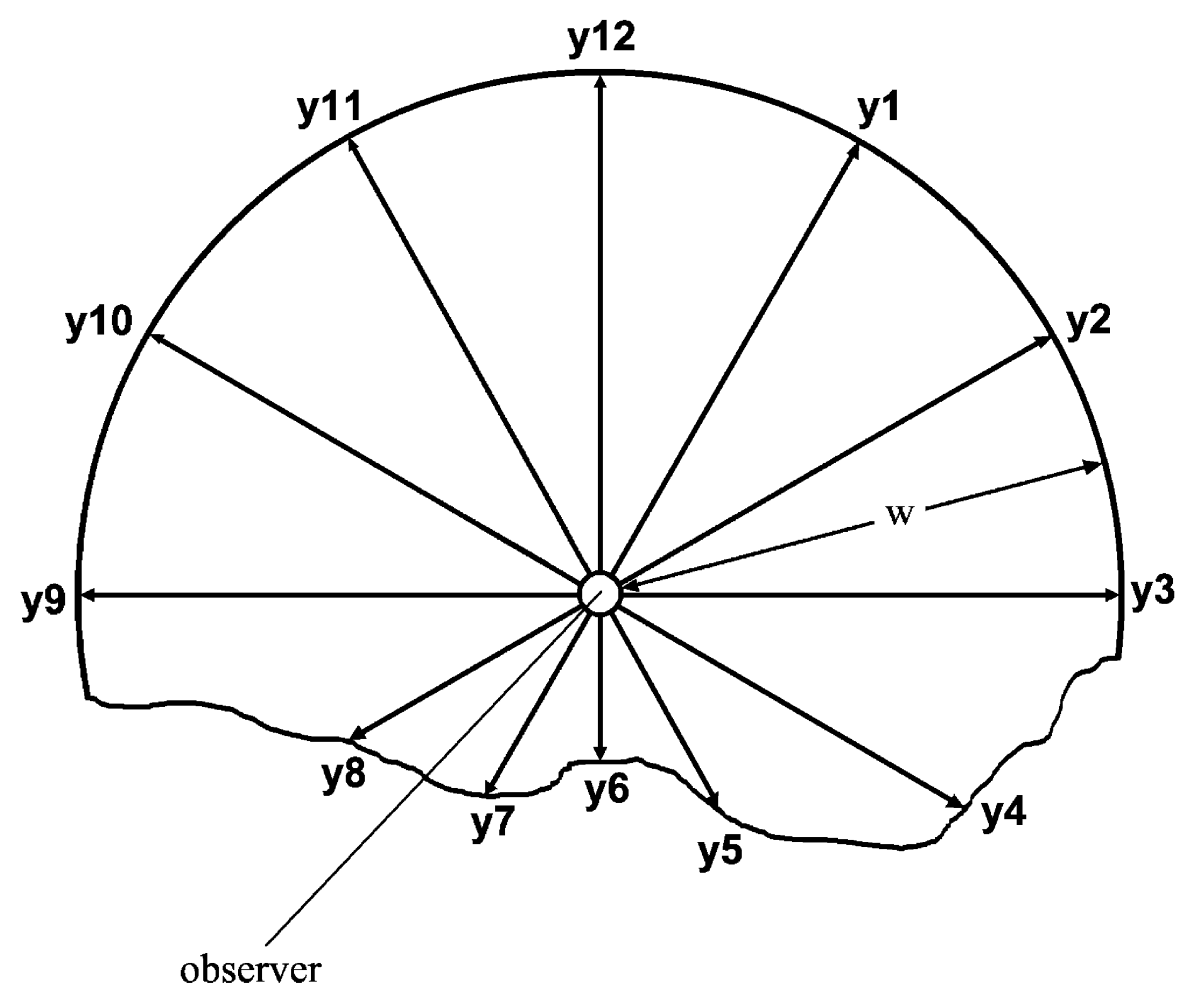

Figure 4. Diagrammatic representation of a point count conducted near to the edge of a swamp with an effective cut-off radial distance. Ground maps were used to mark the boundary of the swamp. 
The average probability of detecting birds $\left(P_{\mathrm{a}}\right)$ within any given distance, $w$ is given by the following equation (see Buckland et al. 1993 for details):

$$
P_{a}=\frac{2 \int_{0}^{w} r \cdot g(r) d r}{w^{2}}
$$

where: $\quad r$ is the distance from the observer.

$\mathrm{g}(\mathrm{r})$ is the probability of detection function - function that describes the probability that an object at distance, $r$ from the observer will be detected, scaled such that $g(0)=1$.

From (2), the mean probability of detection is thus given by:

$$
P_{a}=\frac{1}{12} \sum_{n=1}^{12} \frac{2 \int_{0}^{y_{n}} r \cdot g(r) d r}{\mathrm{y}_{n}^{2}}
$$

and combining (1) and (3) gives the area/detectability product $\left(a_{\mathrm{s}} P_{\mathrm{a}}\right)$ :

$$
a_{s} P_{a}=\frac{\pi}{12} \sum_{n=1}^{12} y_{n}^{2} \cdot \frac{1}{12} \sum_{n=1}^{12} \frac{2 \int_{0}^{y_{n}} r \cdot g(r) d r}{y_{n}^{2}}
$$

Probability of detection functions were integrated numerically using the Newton-Cotes rule (see Keast and Fairweather 1987) as there is no general solution to their integral. Cut-off distances were then estimated for all other point counts using the above formula to give an equal detection/area product value. This entailed using ground maps to estimate $y$ values and selectively trying out different cut-off distance values until the correct detection / area product value was obtained. A simple programme using MAPLE $\mathrm{V}$ release 4 for Windows was written to do these calculations.

Appendix 2. Species list of birds recorded by point counts in six swamps in Uganda and Kenya (JulyAugust 2001) and the guilds to which they have been allocated.

Hamerkop Scopus umbretta

Hadada Bostrychia hagedash

White-spotted Flufftail Sarothrura pulchra

Black Crake Amaurornis flavirostris

Purple Swamphen Porphyrio porphyrio

African Jacana Actophilornis africana

African Green Pigeon Treron calva

Red-eyed Dove Streptopelia semitorquata

Ring-necked Dove Streptopelia capicola

Great Blue Turaco Corythaeola cristata

Eastern Grey Plantain-eater Crinifer zonurus

Red-chested Cuckoo Cuculus solitarius

Dusky Long-tailed Cuckoo Cercococcyx mechowi

Klaas's Cuckoo Chrysococcyx klaas

Blue-headed Coucal Centropus monachus

African Pygmy Kingfisher Ceyx picta

Malachite Kingfisher Corythornis cristata

Pied Kingfisher Ceryle rudis

Little Greenbul Andropadus virens

Common Bulbul Pycnonotus barbatus

Snowy-crowned Robin-Chat Cossypha niveicapilla

Little Rush Warbler Bradypterus baboecala

White-winged Swamp Warbler Bradypterus carpalis

African Reed Warbler Acrocephalus baeticatus

Greater Swamp Warbler Acrocephalus rufescens

Lesser Swamp Warbler Acrocephalus gracilirostris

Papyrus Yellow Warbler Chloropeta gracilirostris

Red-faced Cisticola Cisticola erythrops

Singing Cisticola Cisticola cantans

Winding Cisticola Cisticola galactotes
Swamp-opportunist

Generalist

Generalist

Swamp-opportunist

Swamp-opportunist

Open water associated

Generalist

Generalist

Generalist

Generalist

Generalist

Generalist

Generalist

Generalist

Swamp-opportunist

Generalist

Open water associated

Open water associated

Generalist

Generalist

Generalist

Swamp-reliant

Papyrus-restricted

Swamp-reliant

Papyrus-restricted

Swamp-reliant

Papyrus-restricted

Swamp-opportunist

Generalist

Swamp-opportunist 
Carruthers's Cisticola Cisticola carruthersi

White-chinned Prinia Schistolais leucopogon

Bleating Warbler Camaroptera brachyura

Grey-capped Warbler Eminia lepida

Swamp Flycatcher Muscicapa aquatica

Arrow-marked Babbler Turdoides jardineii

Western Olive Sunbird Cyanomitra obscura

Red-chested Sunbird Cinnyris erythrocerca

Variable Sunbird Cinnyris venusta

Tropical Boubou Laniarius aethiopicus

Papyrus Gonolek Laniarius mufumbiri

Purple-headed Glossy Starling Lamprotornis purpureiceps

African Citril Serinus citrinelloides

Papyrus Canary Serinus koliensis

Streaky Seedeater Serinus striolatus

Grey-headed Negrofinch Nigrita canicapilla

White-collared Olive-back Nesocharis ansorgei

Red-headed Bluebill Spermophaga ruficapilla

Red-billed Firefinch Lagonosticta senegala

Common Waxbill Estrilda astrild

Black-headed Waxbill Estrilda atricapilla

Slender-billed Weaver Ploceus pelzelni

Spectacled Weaver Ploceus ocularis

Northern Brown-throated Weaver Ploceus castanops

Yellow-backed Weaver Ploceus melanocephalus

Grosbeak Weaver Amblyospiza albifrons
Papyrus-restricted

Generalist

Generalist

Generalist

Swamp-opportunist

Generalist

Generalist

Swamp-opportunist

Generalist

Generalist

Papyrus-restricted

Generalist

Generalist

Papyrus-restricted

Generalist

Generalist

Generalist

Generalist

Generalist

Generalist

Generalist

Swamp-opportunist

Generalist

Swamp-opportunist

Swamp-opportunist

Generalist

Notes on habitat guild are taken from Mackworth-Praed and Grant (1960) from the African Citril to the Grosbeak Weaver and Fry et al. (2000) for all other species.

\section{References}

Barlow, J., Haugaasen, T. and Peres, C. (2002) Effects of ground fires on understorey bird assemblages in Amazonian forests. Biol. Conserv. 105: 157-169.

Begon, M., Harper, J. L. and Townsend, C. R. (1996) Ecology: individuals, populations and communities. Oxford: Blackwell Science.

Bennun, L.A. and Njoroge, P. (1999) Important Bird Areas in Kenya. Nairobi, Kenya: The East African Natural History Society.

BirdLife International (2000) Threatened birds of the world. Barcelona and Cambridge, UK: Lynx Edicions and BirdLife International.

Boar, R.R., Harper, D.M. and Adams, C.S. (1999) Biomass allocation in Cyperus papyrus in a tropical wetland, Lake Naivasha, Kenya. Biotropica 31: 411-421.

Britton, P. L. (1978) Seasonality, density and diversity of birds of a papyrus swamp in western Kenya. Ibis 120: 450-466.

Brown, K. S. and Hutchings, R. W. (1997) Disturbance, fragmentation, and the dynamics of diversity in Amazonian forest butterflies. Pp. 91-110 in W. F. Laurance and R. O. Bierregaard, eds. Tropical forest remnants: ecology, management, and conservation of fragmented communities. Chicago: The University of Chicago Press.

Buckland, S. T., Anderson, D. R., Burnham, K. P. and Laake, J. L. (1993) Distance sampling: estimating abundance of biological populations. London: Chapman and Hall.

Connell, J. H. (1978) Diversity in tropical rainforests and coral reefs. Science 199: 1302-1310. Fry, C. H., Keith, S. and Urban, E. K. (2000) The birds of Africa, I-IV. London: Academic Press.

Hamer, K. C., Hill, J. K., Lace, L. A. and Langan, A. M. (1997) Ecological and biogeographical effects of forest disturbance on tropical butterflies of Sumba, Indonesia. J. Biogeogr. 24: 67-75. 
Hurlbert, S.H. (1971) The non-concept of species diversity: a critique and alternative parameters. Ecology 52: 577-586.

Keast, P. and Fairweather, G. (1987) Numerical integration: recent developments, software and applications. Dordrecht: Reidel.

Mackworth-Praed, C. W. and Grant, C. H. B. (1960) Birds of eastern and north eastern Africa, 2. London: Longman.

Mafabi, P. (2000) The role of wetland policies in the conservation of waterbirds: the case of Uganda. Ostrich 71: 96-98.

Muriuki, J. N., De Klerk, H. M., Williams, P. H., Bennun, L. A., Crowe, T. M. and Vanden Berge, E. (1997) Using patterns of distribution and diversity of Kenyan birds to select and prioritise areas for conservation. Biodivers. Conserv. 6: 191-210.

Muthuri, F. M., Jones, M. B. and Imbamba, S. K. (1989) Primary productivity of papyrus (Cyperus papyrus) in a tropical swamp: Lake Naivasha, Kenya. Biomass 18: 1-14.

O'Connell, T. J., Jackson, L. E. and Brooks, R. P. (1998) A bird community index for biotic integrity for the mid-Atlantic Highlands. Environ. Monit. Assess. 51: 145-156.

Thomas, L., Laake, J. L., Derry, J. F., Buckland, S. T., Borchers, D. L., Anderson, D. R., Burnham, K. P., Strindberg, S., Hedley, S. L., Burt, M. L., Marques, F. F. C., Pollard, J. H. and Fewster, R. M. (1998) Distance 3.5. Research Unit for Wildlife Population Assessment, University of St Andrews, U.K. Available at http://www.ruwpa.st-and.ac.uk/ distance/

Vande weghe, J.-P. (1981) L'avifaune des papyraies au Rwanda et au Burundi. Gerfaut 71: 489-536.

White, P. S. and Pickett, S. T. A. (1985) Natural disturbance and patch dynamics: an introduction. Pp. 3-13 in S. T. A. Pickett and P. S. White, ed. The ecology of natural disturbance and patch dynamics. Orlando, FL: Academic Press.

ILYA MACLEAN ${ }^{1}$, MARK HASSALL and ROSALIND BOAR

Centre for Ecology, Evolution and Conservation, School of Environmental Sciences, University of East Anglia, Norwich, NR4 7TJ; Tel: +44 (o)1603 593 390; Fax: +44 (o)1603 507 719; E-mail: i.maclean@uea.ac.uk

OLIVER NASIRWA

Department of Ornithology, National Museums of Kenya, P.O. Box 40658, Nairobi, Kenya.

${ }^{1}$ Corresponding author

Received 7 May 2002; revision accepted 30 April 2003 
